\title{
Government Responsibility for The Fulfillment Basic Rights of Unprosperous people In Education Sector
}

\author{
Pipi Susanti ${ }^{1}$, Rafiqa Sari ${ }^{2 \Omega}$ \\ ${ }^{1}$ Faculty of Law, Universitas Bengkulu \\ ${ }^{2}$ Faculty of Law, Universitas Bangka Belitung \\ ^email correspondence: rafiga-sari@ubb.ac.id
}

\begin{abstract}
In fact, there are still many people living in poverty where they cannot fulfill their basic needs, be it food or clothing, there are still many children who drop out of school which causes ignorance. Education is one of the things that can change a family to be prosperous, therefore the government is obliged to fulfill this right. The problem in this paper is what form of government responsibility to fulfill the basic rights of the unprosperous people in education? The writing method used is normative with more emphasis on positive legal norms in the form of statutory regulations. The result of the discussion of this writing is that education is the basic right of the unprosperous people fulfilled by the government. In carrying out its responsibilities, the government fulfills the basic rights of the unprosperous people in several programs. Education which is the basic right of the unprosperous people is provided by the social service through PKH, while the Education Office provides these rights through (PIP) As stated in Article 31 of the 1945 Constitution, the community is required to get education and the government is responsible for this, with the some Indonesian program has fulfilled the rights of the unprosperous people in education.
\end{abstract}

Keywords: Government Responsibility; Rights of the Unprosperous People; Human Rights; Education;

Date of Submission: November 23, 2020

Date of Publication: June 10, 2021

DOI: http://dx.doi.org/10.33096/substantivejustice.v4i1.106

\section{INTRODUCTION}

The entire system of state administration is intended to realize national goals so as to advance all aspects of the life of the community, nation and state. The essence of development as an effort to improve the quality of human life through a structured, systematic and sustainable process of social change is the meaning of national development. In reality, human needs cannot be met even after a long time of development. This can be seen from the many needs of the unprosperous people that have not been met. This kind of development should not 
only be carried out by the government, but there must be cooperation from citizens so that this national goal can be realized.

The needs of life can be met with the effort of the results that are made, humans have various needs. Humans want their needs to be well met every time. Conflicts can occur if at the same time two individuals want their needs to be fulfilled only with the same object, where neither of them wants to budge, as well as in human relations if the obligations of one individual and another are not fulfilled. ${ }^{1}$ Inadequate human resources cause social welfare problems to become increasingly complex and large, where the unprosperous people, neglected children, and beggars are increasing. The government and society pay less attention to their welfare, causing the inability to meet basic needs in living their life.

The Poverty Line in March 2020 was recorded at IDR 454,652/capita/month with the composition of the Food Poverty Line of IDR 335,793,- (73.86 percent) and the Non-Food Poverty Line of IDR 118,859 (26.14 percent). The number of unprosperous people is 26.42 million people, an increase of 1.63 million people. In March 2020 Indonesia had a unprosperous people household of 4.66 household members on average, the average poverty line per household was IDR 2,118,678,-/unprosperous people household/month. ${ }^{2}$

The increasing number of people is one of the causes of the escalating number of the unprosperous people, where these people are unable to meet their daily needs, both food and clothing, due to the difficulty of getting proper work. There are limited employment opportunities where the unprosperous people are unable to compete for jobs because of low education. Many unprosperous people drop out of school due to their inability to pay for education, this causes an increase in ignorance and backwardness, even though the rights of the unprosperous people have been regulated in our constitution.

The rights of the unprosperous people are regulated in the 1945 Constitution of the Republic of Indonesia Article 34 paragraph (1) the unprosperous people and neglected children are maintained by the state, paragraph (2) The state develops a social security system for all the people and empowers the weak and unable to comply with human dignity, paragraph (3) the State is responsible for the provision of appropriate health care facilities and public service facilities, paragraph (4) Further provisions regarding the implementation of this article are regulated in law. The guarantee of legal protection related to the social conditions of the community is also regulated in Article $28 \mathrm{H}$ paragraph (1) which states "Everyone has the right to live in physical and spiritual prosperity, to have a place to live, and to have a good and healthy living environment and the right to health services. While Article $28 \mathrm{H}$ paragraph (3) reads "Everyone has the right to social security that allows his full development".

\footnotetext{
1 Djamali, R. A. (2009). Pengantar Hukum Indonesia (Revisi). PT. RajaGrafindo Persada, Jakarta. p.1

2 BPS-Statistics Indonesia (2020, July 15). The percentage of poor population in March 2020 rose to 9.78 percent. Badan Pusat Statistik. Retrieved July 15, 2020, from https://www.bps.go.id/pressrelease/2020/07/15/1744/persentase-penduduk-miskin-maret-2020-naik-menjadi-9-78persen.html and https://www.bps.go.id/website/materi ind/materiBrslnd-20200715120937.odf p.35
} 
At present, many unprosperous people are unable to meet their needs, be it clothing and food. The government regulates the handling of the unprosperous people in Law Number 13 of 2011 in this Law stipulates the rights that can be obtained by the unprosperous people, Article 3 of Law Number 13 of 2011 states "the unprosperous people have the right to adequate food, clothing and housing, obtain health services and obtain an education that can increase their dignity".

Education is one of the most basic rights that must be owned by everyone. ${ }^{3}$ The right to education is an essential right that must be fulfilled, education is one indicator that determines whether a country is categorized as a unprosperous people country, a developing country or even a developed country. ${ }^{4}$ Community welfare can be achieved if the right to education is fulfilled by the government. The right to education is a part of human rights, human rights are rights created by God Almighty that should not be violated, eliminated by anyone related to dignity, and are basic rights that humans have from birth. ${ }^{5}$ Human rights come from God as the creator of the universe and its contents cannot be reduced (non derogable rights) sourced from the State and law. ${ }^{6}$ The basic rights of the unprosperous people are no exception.

As mandated in the Constitution that the highest power holder is the government which has the right to manage and regulate its household, as stated in the preamble of the 1945 Constitution "The state is obliged to protect the entire Indonesian nation and promote social welfare in the context of realizing social justice for all Indonesian people." The right to education is regulated in the Fourth Paragraph of the Preamble and Article 31 of the 1945 Constitution of the Republic of Indonesia (UUD NRI) which stipulates that the goals of the state/government are to promote public welfare, educate the nation's life, and participate in carrying out world order based on independence, eternal peace, and social justice". The right to education as stated in the article above is the obligation of the government/state to fulfill it without distinguishing between economic, social, ethnic, religious, and racial conditions. This becomes the basis for the unprosperous people to be able to develop themselves and obtain a proper education.

Cooperation between the government and the community is needed in dealing with poverty. ${ }^{7}$ Improving the welfare and standard of living of the unprosperous people is carried out in a planned and gradual way through educational infrastructure programs. Education guarantees for the community need to be protected as regulated in the 1945 Constitution. In its implementation, the government plays a role in the survival and welfare of the community. So, the problems that will be discussed in this paper can be formulated as follows: What is the Form

${ }^{3}$ Mudyahardjo, R. (2016). Pengantar Pendidikan, Sebuah Studi Tentang Dasar-Dasar Pendidikan Pada Umumnya dan Pendidikan di Indonesia, PT RajaGrafindo, Jakarta, p. 3.

${ }^{4}$ Rohovenko, O. V., Zapara, S. I., Melnik, N. M., \& Cramar, R. I. (2017). The current status of the local selfgovernment reform in Ukraine: preliminary conclusions and outlook. J. Advanced Res. L. \& Econ., 8, p. 180. DOI: https://doi.org/10.14505/iarle.v8.1(23).20

${ }^{5}$ Hakim, A. A. (2011). Negara Hukum dan demokrasi di Indonesia. Pustaka Pelajar. Yogyakarta, p. 66 Jakarta. $p, 10$

${ }^{6}$ Abdullah, R. (2002). Perkembangan HAM dan keberadaan peradilan HAM di Indonesia. Ghalia Indonesia,

${ }^{7}$ Qamar, N. (2012). Pengantar Politik Hukum Ketatanegaraan. Pustaka Refleksi, Makassar. p, 17 
of Government Responsibility for Fulfilling the Basic Rights of the Unprosperous people in the Education Sector?

\section{RESEARCH METHOD}

This research is normative legal research to studies emphasize positive legal norms in the form of statutory regulations. The study of normative legal research is studying law in the literature, for example, positive legal inventory research, research on legal principles, court decisions, legal theories, and opinions of leading scholars, research on legal systematics, and research on the level of a vertical and horizontal synchronization. ${ }^{8}$ Normative legal research is a process to find a rule of law, legal principles, and legal doctrines to answer the legal issues faced. ${ }^{9}$ This paper with legal research is often conceptualized as what is contained in laws and regulations, or the law is conceptualized as a rule or norm that is used as a benchmark that is considered appropriate in human behavior. ${ }^{10}$ This research was conducted by examining library materials in the form of laws and regulations relating to the basic rights of the unprosperous people in the field of education and how the government's responsibility to fulfill these rights is manifested. Then added secondary materials and data were obtained from the field.

\section{DISCUSSION}

\section{The Form of Government Responsibility in Fulfilling the Basic Rights of the Unprosperous people in the Education Sector}

The state is born from the needs and desires of humans who form a group. The group then developed into an organization to meet the needs and aspirations of community groups to live in an area with a sovereign government. The state is a forum (form) for the people to carry out an organization, generally making it easier for its people to achieve the expected common goals. There are three divisions of state duties. ${ }^{11}$ First, residents get protection in certain areas. Second, providing services to the community in the cultural, economic, and social sectors. Third, when there is a conflict between individuals in society, the state becomes an impartial arbiter and guarantees basic justice in social relations.

In realizing the goals of the state to achieve prosperity carried out by the government. The government is the main instrument used to carry out state duties, that the function of the state/government is the function of regulation, service, empowerment, and development. ${ }^{12}$

In carrying out its responsibility to prosper and educate people's lives, the government established a regulation for handling the unprosperous people on August 18, 2011, where the

\footnotetext{
${ }^{8}$ Adang, A. Y. (2008). Pengantar Sosiologi Hukum, Kompas Gramedia, Jakarta, p. 83.

${ }_{9}^{9}$ Marzuki, P. M. (2010). Penelitian Hukum, Kencana Prenada, Jakarta, p. 35.

${ }^{10}$ Azikin, Z. (2006). Pengantar Metode Penelitian Hukum, Jakarta, PT. Raja Grafindo Persada, p. 118.

${ }_{11}$ Pudyatmoko, Y. S. (2009). Perizinan: problem dan upaya pembenahan. Grasindo, Jakarta, p.2

12 Muhadam, L. (2006). Memahami Ilmu Pemerintahan Suatu Kajian Teori, Konsep dan Pengembangannya. Rajawali Pers, Jakarta, p. 32.
} 
law is known as Law Number 13 of 2011 concerning Handling the Unprosperous people. ${ }^{13}$ National development is not only infrastructure development but also development that pays attention to the fulfillment of community needs, such as the unprosperous people who need to be considered in fulfilling their basic needs properly. By meeting their basic needs, it can improve the lives of the unprosperous people. One of these basic rights is the right to education.

The state is responsible for caring for the unprosperous people and neglected children, in this case, the government makes policies and programs that favor the unprosperous people in a planned, targeted, and sustainable manner. Policies and regulations regarding the fulfillment of basic needs for the unprosperous people are regulated in several laws and regulations, Law Number 13 of 2011 concerning Handling the Unprosperous people was established so that the arrangements for handling the unprosperous people are coordinated in obtaining an education. The regulation regarding the unprosperous people and neglected children is also contained in Article 34 of the 1945 Constitution. This is in line with Sri Soemantri's opinion (2006) that a constitution generally contains three main things, namely: first, the guarantees for human rights and citizens; second, the stipulation of the constitutional structure of a state which is fundamentals; third, there is a division and limitation of constitutional tasks which are also fundamental. ${ }^{14}$

The most essential rights possessed by humans are human rights, one of which is the right in the field of education. Education is one of the most basic rights that must be owned by everyone. ${ }^{15}$ Education is needed by citizens to educate themselves and provide a good future. The regulation regarding education is also regulated in the 1945 Constitution contained in Article 31 Paragraph (1-5) of the 1945 Constitution of the Republic of Indonesia which reads:

1) Every citizen has the right to education.

2) Every citizen is obliged to attend basic education and the government is obliged to pay for it.

3) The government seeks and organizes a national education system, which increases faith and piety as well as a noble character in the context of the intellectual life of the nation, which is regulated by law.

4) The state prioritizes the education budget at least twenty percent of the state revenue and expenditure budget as well as from the regional revenue and expenditure budget to meet the needs of the implementation of national education.

5) The government advances science and technology by upholding religious values and national unity for the advancement of civilization and the welfare of mankind.

\footnotetext{
${ }^{13}$ Law Number 13 of 2011 concerning Handling of the Unprosperous, State Gazette of the Republic of Indonesia. Number 83 of 2011. Supplement to the State Gazette of the Republic of Indonesia, Number 5235.

${ }^{14}$ Affandi, H. (2017). Tanggung Jawab Negara dalam Pemenuhan Hak atas Pendidikan menurut Undangundang Dasar Tahun1945. Jurnal Hukum Positum, 1(2), 218-243.

${ }^{15}$ Sirait, S. C. (2017). Tanggung Jawab Pemerintah untuk Memberikan Pendidikan kepada Anak Terlantar dalam Perspektif Undang-Undang Perlindungan Anak. DE LEGA LATA: Jurnal IImu Hukum, 2(1), 158-182. DOI: http://dx.doi.org/10.30596\%2Fdll.v2i1.1146
} 
The 1945 Constitution regulates the rights of citizens to obtain basic education and the government's obligations in implementing the education system and the budget used in implementing education. Based on the five paragraphs contained in Article 31 of the 1945 Constitution, it implies that education is very necessary to educate the nation where the government has an important role in advancing science and developing technology. The government is also obliged to organize an education system, it fulfills the rights in education for the community so that welfare can be obtained.

Every citizen has the right to receive welfare in his life as regulated in the opening of the fourth paragraph of the 1945 Constitution and this is also regulated in the body of the 1945 Constitution Article 34 regarding the unprosperous people and neglected children. to take care of the unprosperous people. The main thing is the handling of maintenance and empowerment which does not seem to be understood evenly in all government agencies regarding the mandate of the Constitution to pay attention to marginal groups, such as the unprosperous people. Article 31 concerning education, fulfillment of community rights in the field of education is an obligation for all government officials at every level, be it the central government, provincial governments, and district/city governments to achieve the goals and ideals of the state in advancing welfare.

The protection and development of the right to education can be found in the Millennium Development Goals to include eradicating extreme poverty and hunger, realizing basic education for all. ${ }^{16}$ Protection of the fulfillment of basic needs and education is guaranteed in the 1945 Constitution Article 28C paragraph (1) which states "Education is the right of every citizen, obtaining an education is part of human rights, as contained in Article $28 \mathrm{C}$ paragraph (1) of the Constitution The Republic of Indonesia in 1945 which states: "everyone has the right to develop himself through the fulfillment of his basic needs, has the right to obtain education and benefit from science and technology, art and culture, in order to improve the quality of his life and for the welfare of mankind", Article 28E paragraph (1) where everyone has the right and is given the freedom to develop themselves through the fulfillment of their basic needs, the right to education to improve their welfare and quality of life.

Article 27 of the Universal Declaration of Human Rights regulates the right to receive teaching and education, stating; "Everyone has the right to participate in the cultural life of the community, and to share in the advancement of science and its use and the protection of the moral and material benefits derived from scientific work from any scientific, literary or artistic creations." Every citizen has the same rights in obtaining education, including the unprosperous people, who have the same rights in terms of obtaining an education. The government is responsible for basic education. The community has the freedom to participate in the field of

${ }^{16}$ Sulistyastuti, D. R. (2007). Pembangunan Pendidikan dan MDGs di Indonesia Sebuah Refleksi Kritis. Jurnal Kependudukan Indonesia, 2(2), 19-44. 
science and the freedom to work, thus creating works that provide an assessment for themselves. The right to obtain a proper education is also contained in Article 12 of Law Number 39 of 1999 concerning Human Rights, which states;

"Everyone has the right to protection for his personal development to obtain the education, educate himself, and improve the quality of his life so that he becomes a human being who is faithful, pious, responsible, has a noble character, is happy, and prosperous following human rights."17

The right regarding education for children is affirmed in Article 60 paragraph (1) of the Human Rights Law which reads as follows "Every child has the right to receive education and teaching in the context of his personal development following his interests, talents, and level of intelligence." In other regulates also: ${ }^{18}$

1) Every citizen aged seven to fifteen years must attend basic education.

2) Every citizen is responsible for the continuity of education.

Article 32 paragraph (2) of the 1945 Constitution stipulates that every citizen is obliged to attend basic education, while the government is obliged to finance it. Article 31 paragraphs (3) and (4) emphasizes that the government has an obligation to undertake the implementation of national teaching in the context of the intellectual life of the nation by prioritizing a budget of at least 20 percent of the APBN and APBD.

Article 11 of Law Number 20 of 2003 concerning the National Education System reads as follows: (1) The Government and Regional Governments are obliged to provide services and facilities, and ensure the implementation of quality education for every citizen without discrimination. (2) The Government and Regional Governments are obligated to guarantee the availability of funds for the implementation of education for every citizen aged seven to fifteen years. ${ }^{19}$ The success of education in Indonesia is not only the responsibility of the state but also the responsibility of the community. The implementation of the education system is carried out with the rules contained in the Indonesian Law on the National Education System. The National Education System Law regulates the participation of the community in the democratic education process to educate people. ${ }^{20}$

Education management does not become the domination of the central government but also enlarges the role of local governments in the context of autonomy and decentralization. With Law no. 23 of 2014 concerning Regional Government has changed the constellation of government policies from a centralized system to a decentralized one.

17 Law of The Republic of Indonesia Number 39 of 1999 concerning Human Rights, State Gazette of the Republic of Indonesia. Number 165 of 1999. Supplement to the State Gazette of the Republic of Indonesia, Number 3886.

${ }^{18}$ Article 6 Paragraph (1) Paragraph (2), Law of The Republic Indonesia Number 20 of 2003 concerning the National Education System, State Gazette of the Republic Indonesia, Number 78 of 2003. Supplement to the Gazette of The Republic of Indonesia, Number 4301.

19 Ibid. Article 11

20 Prasetyo, Y. A. (2012, May 28-31). Hak Ekosob dan Kewajiban Negara. [Pemerkuatan Hak Asasi Manusia] Untuk Hakim Seluruh Indonesia, Holiday Resort Lombok, Indonesia. p. 5 
The basic rights of the unprosperous people in the field of education are not only the responsibility of the central government but also the responsibility of the provincial and district/city governments. This is regulated in the Regional Government Law Article 11 Paragraph (1-3) which reads: "Concurrent government affairs as referred to in Article 9 paragraph (3) which become the authority of the Regions consist of Mandatory Government Affairs and Preferred Government Affairs".

The basic services are the government's obligations are "Basic services which are mandatory government affairs include education, health, public works, and spatial planning, public housing and residential areas, peace, public order, and community and social protection". ${ }^{21}$ There has been a democratization of education management where the old paradigm of education that used a centralized system is now decentralized. Local governments are demanded to be more optimal and serious in carrying out development in the education sector so that the rights of the unprosperous people can be fulfilled and can get a decent and prosperous life.

Education is a mandatory government affair, be it the central government, provincial government, or district/city governments, where education is the responsibility of the government that must be fulfilled because education is needed by all citizens, be it the unprosperous people, because education has an influence on their lives in the future. With education, the unprosperous people can improve their lives to a decent life. So in fulfilling the rights of the unprosperous people in the field of education. The government provides the fulfillment of community rights in the education sector through several programs compiled by the central government through the Ministry of Social Affairs which is centralized to the Social Service both at the provincial and district/city levels, one of which is the Family Hope Program while the Ministry of Education through the Education Office uses the Indonesian Program Smart, where this program is a central government program in which the distribution of assistance in the province or district/city is carried out by the district/city social service.

\section{Hope Family Program}

The state has a responsibility to fulfill the rights of the unprosperous people. with the state fulfilling the rights of the unprosperous people, the problem of poverty can be alleviated. One way of poverty alleviation is through education. The right to obtain an education is regulated in-laws and regulations. The government as an education provider in Indonesia is democratic and upholds the values of human rights. Article 28C paragraph (1) of the 1945 Constitution, reads; "Everyone has the right to develop themselves through the fulfillment of their basic needs, the right to an education that benefits from science and technology, art and culture, to improve the quality of life and for the welfare of mankind".

${ }^{21}$ Article 12 Paragraph (1) Law of The Republic Indonesia Number 9 of 2015 concerning Second Amendment to Law Number 23 of 2014 Concerning the Regional Government, State Gazette of the Republic Indonesia, Number 58 of 2015. Supplement to the Gazette of The Republic of Indonesia, Number 5679. 
Based on Article 28C paragraph (1) of the 1945 Constitution, all citizens or communities have the right to have a proper education and provide benefits for themselves and have the right to advance themselves to have a better quality of life in the future. The state and society must respect and uphold these rights. Education is a very important means for human survival, this is because education is a sector that can create human intelligence in carrying out their lives, the importance of education so that all the necessities of life can be obtained easily. This is also no exception for the unprosperous people, they have rights. to be fulfilled in improving education for their children so that the unprosperous people can increase their knowledge and income so that the number of children dropping out of school can be reduced and can increase the value of development, the government and the community must pay more attention and encourage school dropouts for teenagers so that the unprosperous people can improve their lives.

At this time the dropout rate among early childhood is still quite high, this can be seen from the government's lack of seriousness in allocating school operational assistance funds that are not running effectively to areas where there are still many schools that still charge tuition fees. Education outside of school must also be considered by the government, where many children from unprosperous people communities participate in this activity. The Family Hope Program $(\mathrm{PKH})$ is one way to fulfill the basic rights for children of the unprosperous people in the field of education.

In minimizing the unprosperous people to get an education, one of them is with the Family Hope Program (PKH), is an social protection program in the Ministry of Social Affairs where this program provides cash assistance to the unprosperous people. The unprosperous people can receive $\mathrm{PKH}$ assistance with certain conditions. The purpose of this $\mathrm{PKH}$ program is to break the chain of poverty by increasing access and quality of education and health services for PKH participants and increasing the education level of the children of PKH participants by providing cash assistance to the unprosperous people.

$\mathrm{PKH}$ is in the form of assistance given to families because the family is a place to improve human resources. The welfare of children, whether in the health sector, education is the responsibility of the parents. This PKH assistance is provided so that the poverty chain can be broken. PKH assistance is given to the unprosperous people on the condition that the data for the unprosperous people have been recorded in an integrated database, namely the Social Protection Program Data Collection (PPLS) where the recording is carried out by the Central Statistics Agency (BPS). The unprosperous people who receive this assistance must also meet other requirements, i.e, several components must be met, particularly:

a. Health component

b. Educational Component (school-age children, whether they attend a school or outside of school or attend package schools as long as they are 7 to 21 years old) 


\section{c. Social Welfare Component}

In 2014, PKH participants reached 2,871,827 RTM houses in 418 regencies/cities, 4870 subdistricts. In recent time, the number of PKH recipients has spread throughout the provinces, districts/cities in Indonesia.

Fulfillment of the right to education for the unprosperous people is the responsibility and mandatory affair of the Government as regulated in Article 31 of the 1945 Constitution where the state should organize an education system and at the same time finance it to fulfill the right to education for every citizen. The government (central) and local governments are obliged to provide services and facilities and ensure the implementation of quality education for citizens without discrimination. Precisely for this reason, the central and regional governments are obliged to guarantee the availability of funds for the implementation of education for every citizen aged seven to fifteen years. That is why the central/regional government guarantees the implementation of compulsory education, at least basic education is free of charge because compulsory education is the responsibility of the state which is held by the government, local government, and the community. ${ }^{22}$

Article 31 of the 1945 Constitution explains that every citizen can sue the state if he does not get a quality and proper education to raise his dignity and human dignity as well as provisions to improve the quality of his life. This right to education must be given by the state without discriminating against the unprosperous people. If it is not given, the state violates the constitution.

In fulfilling these rights, the government holds the PKH program, it can be said that the government program has been able to fulfill human rights which are the responsibility of the state. As for the government's mandatory affairs regarding the basic rights of the unprosperous people in the field of education. Education is very necessary for citizens to educate themselves, education for the unprosperous people is a basic right that must be fulfilled in accordance with the laws and regulations. The regulation in handling the unprosperous people is regulated in Law Number 13 of 2011, that the unprosperous people have the right to obtain the education that can increase their dignity. Article 16 of Law Number 13 of 2011 "The Government and Regional Governments are Responsible for assisting with education costs or scholarships"23, Article 31 paragraphs (3) and (4) emphasizes that the government must undertake the implementation of national teaching in the context of the intellectual life of the nation by prioritizing a budget of at least 20 percent of the APBN and APBD. The law Through this family program of hope, the Government and Local Governments can fulfill their responsibilities in implementing the fulfillment of the right to education for the unprosperous people, where the unprosperous people receive educational assistance which is obtained once every three

22 Arifin, A. (2005). Paradigma Baru Pendidikan Nasional dalam Undang-Undang SISDIKNAS Nomor 20 Tahun 2003. Balai Pustaka, Jakarta. p. 79

${ }^{23}$ Law Number 13 of 2011, Op. Cit. Article 16 
months to pay for the education of their children who go to school to improve their standard of living.

\section{Smart Indonesia Program (Education Authorities)}

This PIP program is the same as the Unprosperous people Student Assistance (BSM) which was given from 2008 to 2014 and was refined into the Smart Indonesia Program. The Smart Indonesia Program has been given since the end of 2014 which is a complement to the BSM program which has the same goal, namely to provide cash assistance to school students from unprosperous people families. The difference between PIP and BSM is that BSM is only given to students who attend formal educational institutions, while PIP is given to school-age children, both formal and package schools or non-formal schools. As contained in Law no. 20 of 2003, there was a fundamental change regarding school and non-school education pathways, into 3 pathways, as contained in Article 13 of Law no. 20 of 2003, namely: formal education, non-formal education, and informal education.

This assistance is not only given to students attending public schools but also to students attending private schools and Islamic boarding schools. To fulfill the rights of the unprosperous people in the field of education, the government through the Ministry of Education and Culture (Kemendikbud) and the Ministry of Religion (Kemenag) distributes assistance through the Education Office and the Ministry of Religion which oversees schools in the provinces and districts/cities to distribute assistance to underprivileged students. Article 16 of Law no. 13 of 2011 states "Government and local government are responsible for providing assistance in education costs or scholarships". Article 3 C of Law no. 13 of 2011 states "The unprosperous people have the right to get an education that can increase their dignity", with this program the rights of the unprosperous people will be fulfilled in the field of education.

In-Law no. 20 of 2003 several provisions can be considered, among others:

1. Article 5 paragraph (1), that "every citizen has the same right to obtain quality education"

2. Article 11 paragraph (1), that: "the government and local governments are obliged to provide services and facilities and ensure the implementation of quality education for every citizen without discrimination.

3. Article 11 paragraph (2), that: "the government and local governments are obliged to guarantee the availability of a budget for the implementation of education for every citizen aged seven to fifteen years".

The provision of this assistance has been mandated in the Education System Law as stated in Article 11 paragraph (2). Where the purpose of this program is so that underprivileged children are not hampered in getting an education, children who drop out of school can go to school again, and this program also supports reasonableness, namely 9 years of compulsory education and 12 years of compulsory education. With the fulfillment of the rights of the unprosperous people in the field of education, following the state objectives contained in the 
preamble of the 1945 Constitution, namely to form an Indonesian state government that protects the entire Indonesian nation and the homeland of Indonesia, as well as advances general welfare and educates the nation's life.

\section{CONCLUSION}

Every citizen has the equal rights in obtaining education, including the unprosperous people. The government is responsible for basic education as mandated in the 1945 Constitution Article $28 \mathrm{C}$ paragraph 1, and Article 31 Paragraph 1. Education is a basic right, the unprosperous people that must be fulfilled by the government as mandated by law, Article 3C of Law No. 13 of 2011 states: "The unprosperous people have the right to obtain the education that can improve their dignity", where in fulfillment of central orders, provincial and district/city governments have the same obligations. The mandatory government affairs are provided through the Social Service and the Education Office. Education, which is a basic right of the unprosperous people, is provided by the social service through the PKH program, which is originating from the central ministry and handed over to the social service. Through this program, the basic rights of the unprosperous people in the education sector can be fulfilled by the government. As stated in Article 31 Paragraphs 3 and 4 of the 1945 Constitution, the community is obliged to receive education, and the government is obliged to provide services, with the PKH and PIP programs the rights of the unprosperous people in the field of education are fulfilled.

\section{REFFERENCES}

Abdullah, R. (2002). Perkembangan HAM dan keberadaan peradilan HAM di Indonesia. Ghalia Indonesia, Jakarta.

Adang, A. Y. (2008). Pengantar Sosiologi Hukum, Kompas Gramedia, Jakarta.

Affandi, H. (2017). Tanggung Jawab Negara dalam Pemenuhan Hak atas Pendidikan menurut Undang-undang Dasar Tahun1945. Jurnal Hukum Positum, 1(2), 218-243.

Arifin, A. (2005). Paradigma Baru Pendidikan Nasional dalam Undang-Undang SISDIKNAS Nomor 20 Tahun 2003. Balai Pustaka, Jakarta.

Azikin, Z. (2006). Pengantar Metode Penelitian Hukum, Jakarta, PT. Raja Grafindo Persada.

Djamali, R. A. (2009). Pengantar Hukum Indonesia (Revisi). PT. RajaGrafindo Persada, Jakarta

Hakim, A. A. (2011). Negara Hukum dan demokrasi di Indonesia. Pustaka Pelajar. Yogyakarta

Marzuki, P. M. (2010). Penelitian Hukum, Kencana Prenada, Jakarta.

Mudyahardjo, R. (2016). Pengantar Pendidikan, Sebuah Studi Tentang Dasar-Dasar Pendidikan Pada Umumnya dan Pendidikan di Indonesia, PT RajaGrafindo , Jakarta

Muhadam, L. (2006). Memahami Ilmu Pemerintahan Suatu Kajian Teori, Konsep dan Pengembangannya. Rajawali Pers, Jakarta.

Prasetyo, Y. A. (2012, May 28-31). Hak Ekosob dan Kewajiban Negara. [Pemerkuatan Hak Asasi Manusia] Untuk Hakim Seluruh Indonesia, Holiday Resort Lombok, Indonesia. 
Pudyatmoko, Y. S. (2009). Perizinan: problem dan upaya pembenahan. Grasindo, Jakarta.

Qamar, N. (2012). Pengantar Politik Hukum Ketatanegaraan. Pustaka Refleksi, Makassar.

Rohovenko, O. V., Zapara, S. I., Melnik, N. M., \& Cramar, R. I. (2017). The current status of the local self-government reform in Ukraine: preliminary conclusions and outlook. $J$. Advanced Res. L. \& Econ., 8, p. 180. DOI: https://doi.org/10.14505/iarle.v8.1(23).20

Sirait, S. C. (2017). Tanggung Jawab Pemerintah untuk Memberikan Pendidikan kepada Anak Terlantar dalam Perspektif Undang-Undang Perlindungan Anak. DE LEGA LATA: Jurnal IImu Hukum, 2(1), 158-182. DOI: http://dx.doi.org/10.30596\%2Fdll.v2i1.1146

Sulistyastuti, D. R. (2007). Pembangunan Pendidikan dan MDGs di Indonesia Sebuah Refleksi Kritis. Jurnal Kependudukan Indonesia, 2(2), 19-44.

\section{Statutory Regulation}

Constitution of the Republic of Indonesia 1945

Law of The Republic of Indonesia Number 39 of 1999 concerning Human Rights, State Gazette of the Republic of Indonesia. Number 165 of 1999. Supplement to the State Gazette of the Republic of Indonesia, Number 3886.

Law of The Republic Indonesia Number 20 of 2003 concerning the National Education System, State Gazette of the Republic Indonesia, Number 78 of 2003. Supplement to the Gazette of The Republic of Indonesia, Number 4301.

Law Number 13 of 2011 concerning Handling of the Unprosperous, State Gazette of the Republic of Indonesia. Number 83 of 2011. Supplement to the State Gazette of the Republic of Indonesia, Number 5235.

Law of The Republic Indonesia Number 9 of 2015 concerning Second Amendment to Law Number 23 of 2014 Concerning the Regional Government, State Gazette of the Republic Indonesia, Number 58 of 2015. Supplement to the Gazette of The Republic of Indonesia, Number 5679.

\section{Website}

BPS-Statistics Indonesia (2020, July 15). The percentage of poor population in March 2020 rose to 9.78 percent. Badan Pusat Statistik. Retrieved July 15, 2020, from https://www.bps.go.id/pressrelease/2020/07/15/1744/persentase-penduduk-miskin-maret2020-naik-meniadi-9-78-persen.html and https://www.bps.go.id/website/materi ind/materiBrsInd-20200715120937.pdf 